\title{
Late Triassic-Early Jurassic Calcareous Nannofossils of the Queen Charlotte Islands, British Columbia
}

\author{
PAUL R. BOWN \\ Dipartment of Geological Sciences, Micropalaeontology Unit, \\ University College London, Gower Street, \\ London WC1E 6BT, U.K.
}

\begin{abstract}
Sediments of the Kunga and Maude groups (Early Norian-Aalenian) from the Queen Charlotte Islands, British Columbia, have yielded the first records of early Mesozoic calcareous nannofossils in North America. These occurrences are the only record of Triassic nannofossils away from the recent discoveries in the Tethyan area (Austria, Indonesia, and the northwestern Australian margin). The nannofossil assemblages from the Queen Charlotte Islands are generally poor to moderately preserved, with species diversities typical for this time interval (2-10 species). The assemblages are comparable to those from northwest Europe, for the Lower Jurassic, and to those from Austria, Indonesia, and the Australian margin, for the Upper Triassic. They show compatible stratigraphical ranges, allowing the application of existing biostratigraphical zonations. Palaeobiogeographical interpretations are inconclusive and fail to positively confirm a low latitude (Tethyan) position for the Queen Charlotte Islands, as indicated by macrofossil data. However, Triassic nannofossil assemblages have yet to be described from high palaeolatitude locations. In addition, certain features of the Lower Jurassic assemblages may indicate Tethyan affinities but also distinguish these assemblages from those which have been previously documented. These features include the absence of Schizosphaerella punctulata, which occurs abundantly in the circum-Mediterranean region and was previously thought to be "cosmopolitan" in distribution; and the absence of Mitrolithus jansae which characterizes "Tethyan" assemblages in the circum-Mediterranean area. The Queen Charlotte Islands results are compared with new nannofossil data from Argentina, Timor and North America. J. Micropalaeontol., 11 (2): 177 188, December 1992.
\end{abstract}

\section{INTRODUCTION}

Calcareous nannofossils are relatively well studied for much of the Late Cretaceous to Recent interval and provide valuable biostratigraphical and palaeoenvironmental information. From their first appearance in the Late Triassic and through their initial evolutionary diversification during the Jurassic, they are less well known and data are geographically restricted, primarily to the northwest European region. Although advances have been made in biostratigraphical resolution for this time interval, our knowledge of their palaeobiogeography is still rudimentary. At present it is possible to recognise significant differences between northern European (Boreal) and circum-Mediterranean/proto-Atlantic (Tethyan) assemblages, but data from the remainder of Tethys and the Pacific region are extremely rare (Bown, 1987). The discovery of calcareous nannofossils in the Upper Triassic and Lower Jurassic of British Columbia is therefore of interest in terms of testing biostratigraphical schemes established in the European area, and also for determining palaeobiogeographical patterns in a region of the early Mesozoic ocean unstudied by nannofossil workers.

\section{GEOLOGY OF THE QUEEN CHARLOTTE ISLANDS}

The Queen Charlotte Islands are part of the Insular Belt of the Canadian Cordillera, situated at the western edge of the North American continent and separated from the Pacific Ocean floor by the Queen Charlotte Transform Fault. To the east lies

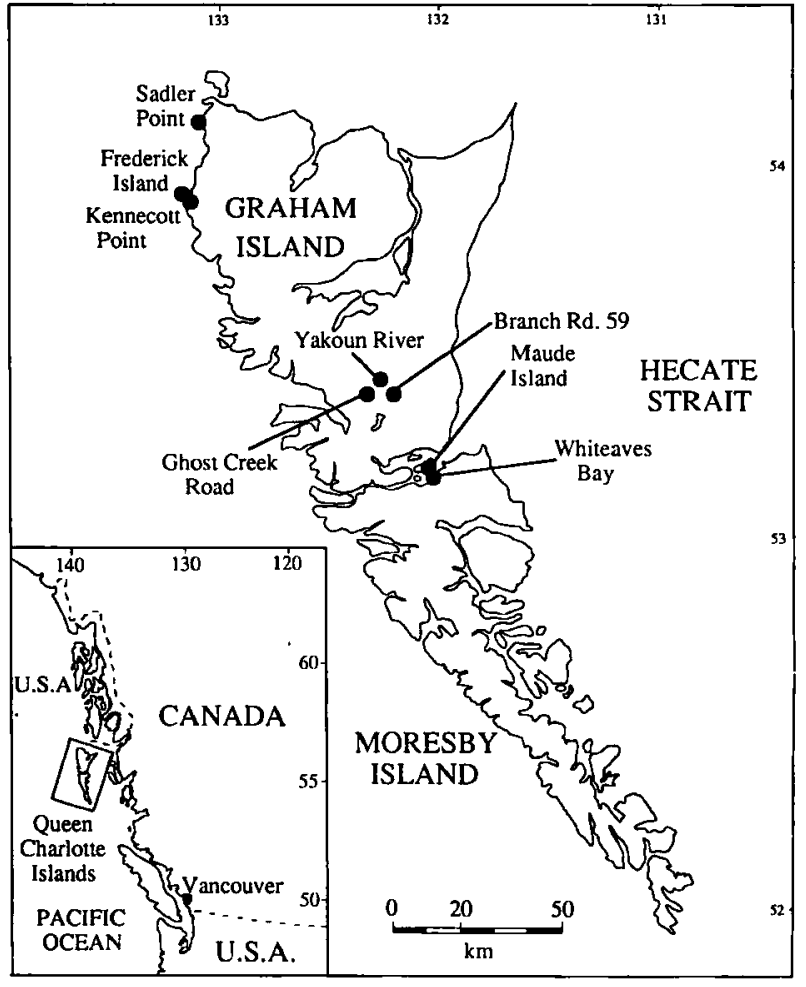

Fig.1. Queen Charlotte Islands location map. 


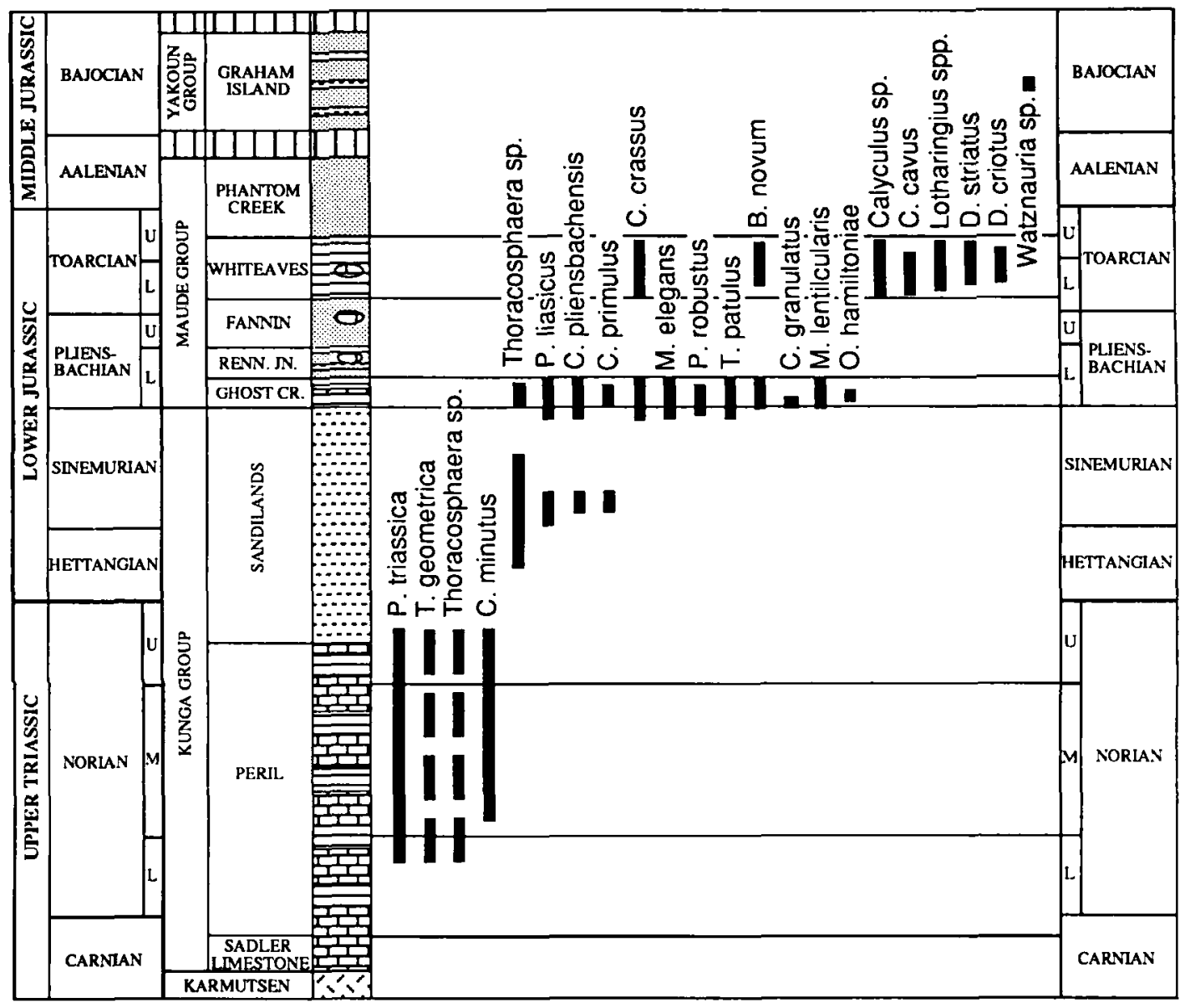

Fig. 2. Composite stratigraphy and nannofossil distribution of lower Mesozoic sequences, Queen Charlotte Islands. Stratigraphy from Carter et al. (1989) and Tipper et al. (1991).

the shallow shelf region of Hecate Strait; to the south, Queen Charlotte Sound and Vancouver Island; and to the north, Dixon Entrance and the Alexander Archipelago of southeast Alaska (Fig. 1). The islands are composed of a varied assemblage of Mesozoic and Cenozoic plutonic, volcanic, metamorphic, and sedimentary rocks (Sutherland Brown et al., 1983). Basement is formed by the Upper Triassic Karmutsen Formation which is predominantly composed of volcanic rocks. There is, however, recent evidence of older, Palaeozoic rocks (Carboniferous-Permian), below the Karmutsen Formation (Hesthammer et al., 1991). Overlying the basement is a relatively complete early Mesozoic sedimentary sequence which ranges from Carnian (Upper Triassic) to Aalenian (Middle Jurassic) and is for the most part only moderately tectonised and of low metamorphic grade (Fig. 2). All units are relatively well dated by integrated ammonite, conodont, and radiolarian studies (e.g. Carter et al.; 1989, Tipper et al., 1991). The lowest unit is the Kunga Group which is Late Triassic to Early Jurassic (Carnian-Sinemurian) in age and divided into three formations: the Sadler Limestone Formation (thicklybedded, dark limestone); the Peril Formation (thinly-bedded dark limestone with subordinate dark shales and siltstone; common Halobia and Monotis bivalves), and the Sandilands
Formation (thinly-bedded and banded, hard, dark siliceous siltstone with interbedded tuff, fine to medium grained sandstone, and shale). The Triassic/Jurassic boundary interval falls within the Sandilands Formation.

Conformably overlying the Kunga Group is the Maude Group, of Early to early Mid Jurassic age (SinemurianAalenian). This unit is divided into five formations: the Ghost Creek Formation (dark grey shale and silty shale, with pale limestone interbeds and lenses); Rennell Junction Formation (fine grained sandstone, argillaceous siltstone, grey shale, and limestone interbeds and lenses); Fannin Formation (sandstone, minor siltstone, and rare tuffaceous shales); Whiteaves Formation (glauconitic, greenish-grey silty shale with minor sandstone interbeds, limestone nodules, and bentonitic ash beds); and Phantom Creek Formation (brown, fine to coarse grained sandstones). The Mid to Late Jurassic succession which includes the Yakoun and Moresby groups is dominated by pyroclastic lithologies, along with conglomerate, shale, and siltstone.

This early Mesozoic sequence is at the western edge of an allochthonous tectonostratigraphic terrane known as Wrangellia. The lithological units can be related to those within the Wrangellia Terrane on Vancouver Island and in 
KENNECOTT POINT - SECTION KP-M

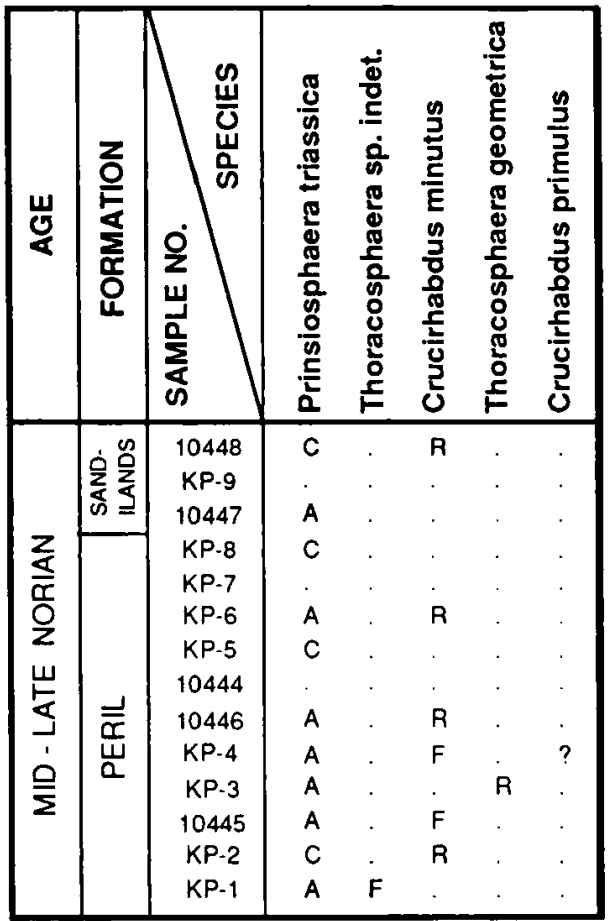

FREDERICK ISLAND - SECTION C

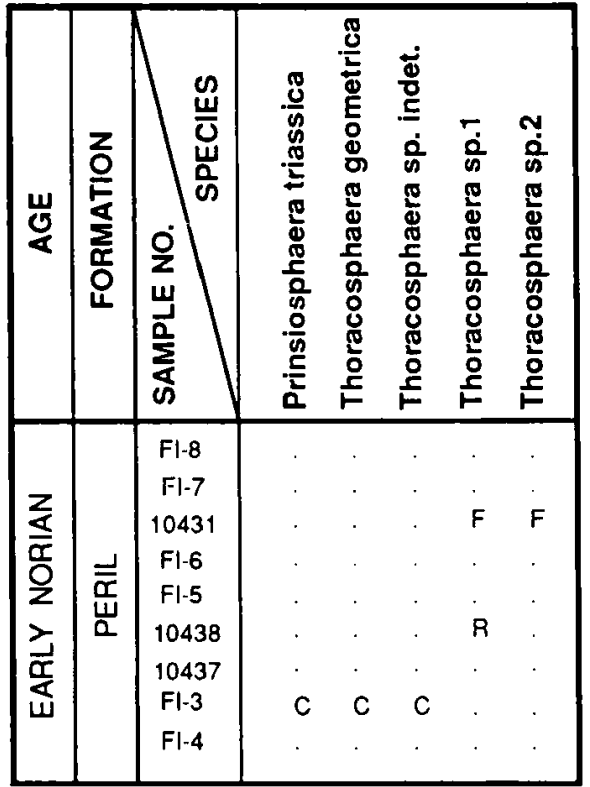

\begin{tabular}{|l|}
\hline \multicolumn{1}{|c|}{ KEY } \\
$R=$ Rare $(0-2$ counts $)$ \\
$F=$ Few $(3-5$ counts $)$ \\
$C=$ Common $(6-100$ counts $)$ \\
$A=$ Abundant $(101-1000$ counts $)$ \\
$V A=$ Very abundant $(>1001$ counts $)$ \\
$?=$ Questionably present \\
$=$ = Not present
\end{tabular}

FREDERICK ISLAND - SECTIONE

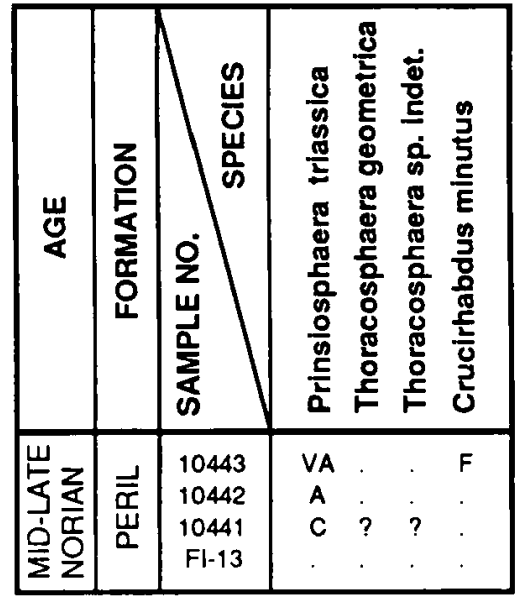

FREDERICK ISLAND - SECTION D

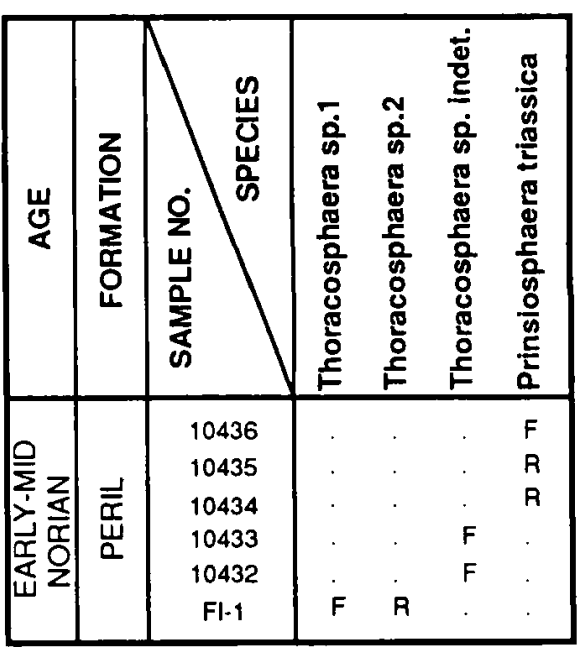

KENNECOTT POINT - SECTIONX

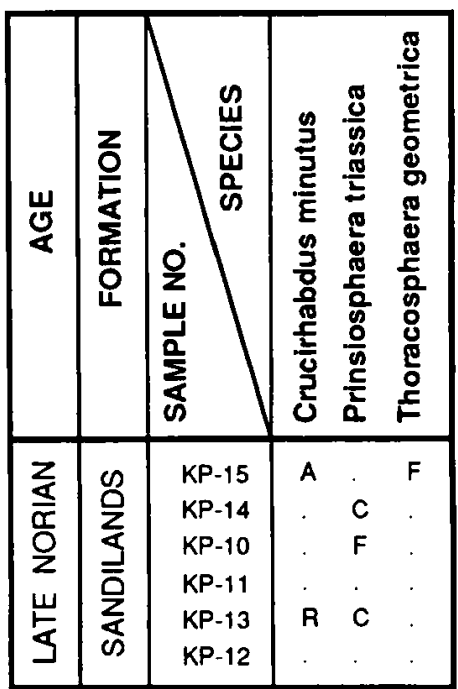

Fig.3. Stratigraphical distribution of nannofossils from Upper Triassic sections of the Queen Charlotte Islands. 
MAUDE ISLAND

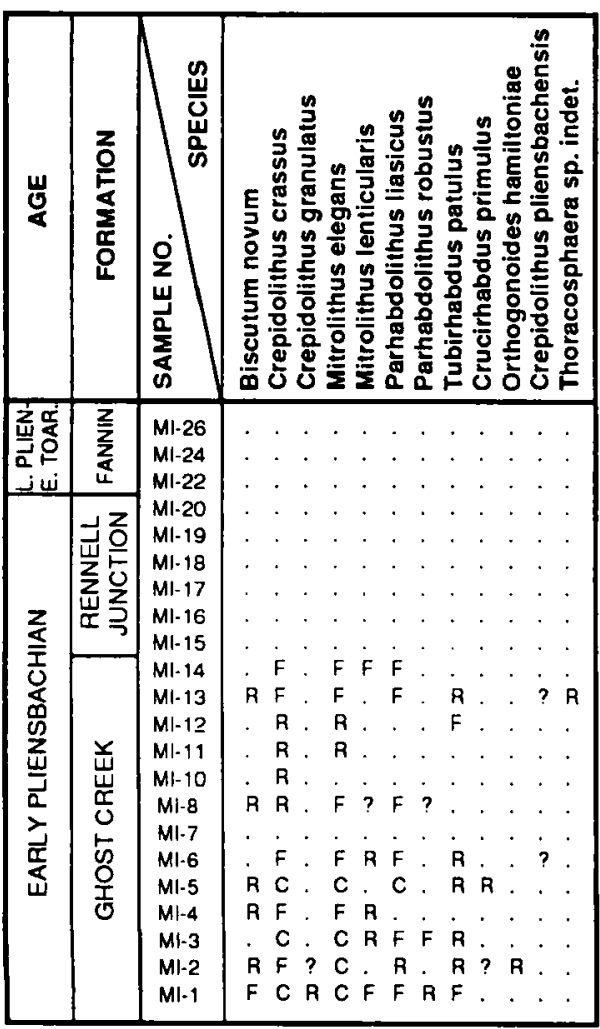

GRAHAM ISLAND - YAKOUN RIVER

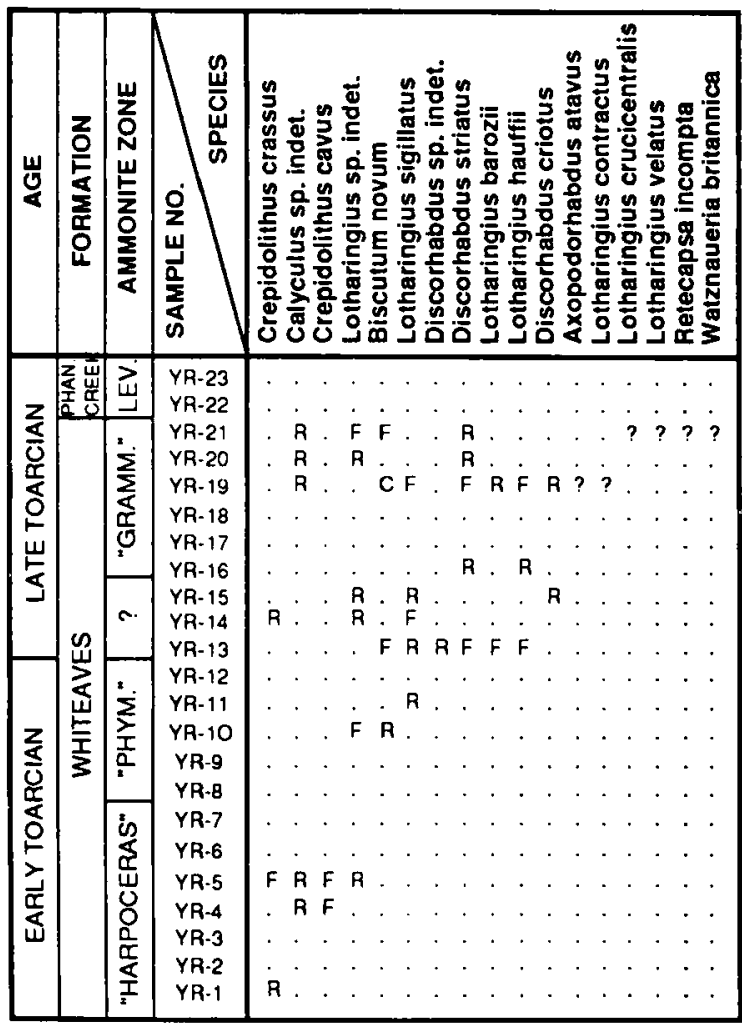

MORESBY ISLAND - WHITEAVES BAY

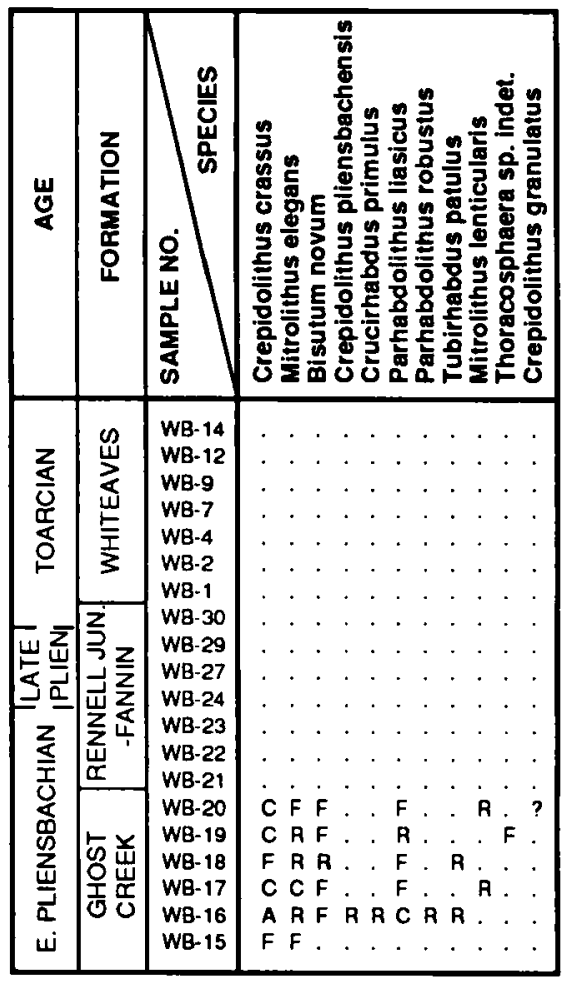

GRAHAM ISLAND. GHOST CREEK ROAD

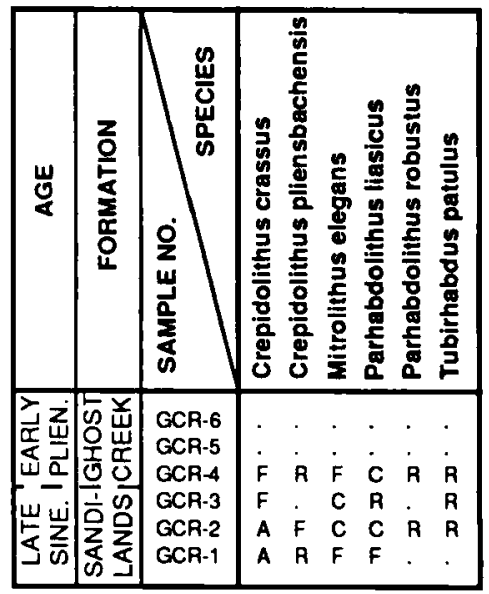

\section{KEY}

$\mathrm{R}=$ Rare $(0-2$ counts $)$

$\mathrm{F}=$ Few (3-5 counts)

$\mathrm{C}=$ Common $(6-100$ counts $)$

$A=$ Abundant (101-1000 counts)

$\mathrm{VA}=$ Very abundant ( $>1001$ counts)

$?=$ Questionably present

$=$ Not present

Fig. 4. Stratigraphical distribution of nannofossils from Jurassic sections of the Queen Charlotte Islands. 
mainland British Columbia. The palaeogeographical setting is thought to be that of a back-arc basin adjacent to the North American craton. The sediments were deposited in a marine basin of fluctuating water depth which was periodically euxinic, and received variable amounts of volcanic detritus. Vulcanism was sporadic through the Late Triassic and Early Jurassic but became more persistent in the Mid Jurassic (Cameron and Tipper, 1985). Macropalaeontological, stratigraphical, and palaeomagnetic evidence suggest that the Wrangellia terrane has undergone post-Pliensbachian latitudinal displacement of around $2400 \mathrm{~km}$, moving north from a more "equatorial" position in the northern hemisphere, eastern Pacific (Smith and Tipper, 1989).

\section{NANNOFOSSIL RESULTS}

1. Calcareous nannofossils from the Queen Charlotte Islands A total of 200 samples were collected from the Kunga and Maude groups (Upper Triassic to Middle Jurassic) during the 1990 field season. 75 of these, from throughout the stratigraphical interval, yielded calcareous nannofossils. The nannofossil assemblages are generally poorly preserved and of low abundance and diversity. The best preservation was observed in the Peril (Norian) and Ghost Creek (Lower Pliensbachian) formations; poor preservation and patchy occurfence was observed in the Sandilands (Norian-Sinemurian) and Whiteaves (Toarcian) formations. The Rennell Junction, Fannin, and Phantom Creek formations were barren. A summary of the stratigraphical distribution of nannofossils is given in Fig. 2 and individual sections in Figs. 3, 4 and 5.

Norian. Sections of the Peril Formation and Sandilands Formation on Frederick Island, and at Kennecott Point on Graham Island(Fig. 1), yielded rare to abundant Upper Triassic nannofossil assemblages. The assemblages are dominated by Prinsiosphaera triassica together with rarer Thoracosphaera geometrica, Thoracosphaera spp. and Crucirhabdus minutus. The lower Peril Formation (Early Norian) sampled at Sadler Point (Graham Island) was barren. The highest productive Triassic sediments were from the lower Sandilands Formation at Kennecott Point of Late Norian age. The Sandilands sediments spanning the Triassic/Jurassic boundary were barren.

These assemblages are comparable to previously reported Late Triassic assemblages from Tethys, but are lacking Eoconusphaera zlambachensis (which is common in the Northern Calcareous Alps, Austria), and contain a slightly more diverse Thoracosphaera assemblage.

Hettangian. At Kennecott Point, the Hettangian Sandilands sediments yielded only fragments of Thoracosphaera sp. indet. Thoracospheres have notbeen previously reported from rocks of Early Jurassic age.

Sinemurian. Sandilands sediments of Sinemurian age were sampled at Kennecott Point and yielded fragments of Thoracosphaera sp. indet. with rare and poorly preserved coccoliths, such as Crepidolithus pliensbachensis, Crucirhabdus primulus and Parhabdolithus liasicus (Fig. 5).

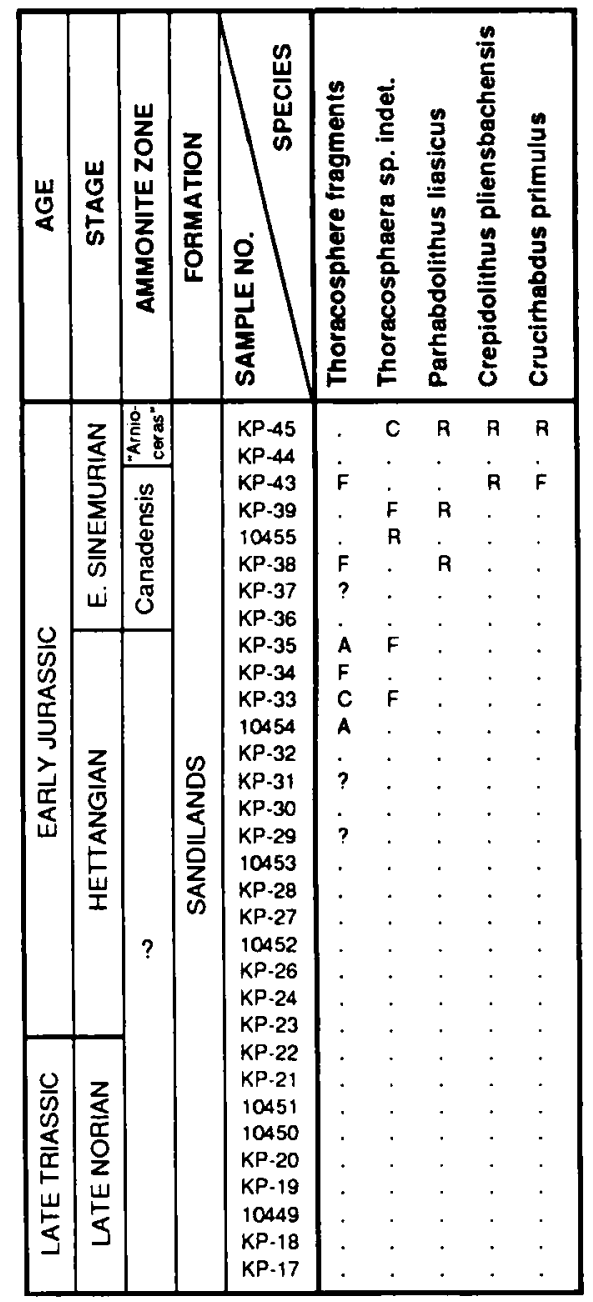

Fig. 5. Stratigraphical distribution of nannofossils from Kennecott Point, Queen Charlotte Islands.

These coccolith assemblages are dated as NJ2 Parhabdolithus liasicus Nannofossil Zone (bucklandi Ammonite Zone-obtusum Ammonite Zone) (Bownet al., 1988) which is stratigraphically compatible, i.e. time equivalent, with the Canadensis Ammonite Zone-Arnioceras assemblage "Zone" given by ammonites (Tipper et al., 1991). (Nannofossil zones will be indicated in the text by a number and the prefix $\mathrm{NJ}$, and refer to the biozonation scheme of Bown et al. (1988). Ammonite zones will be indicated by the abbreviation Am.). The occurrence of $C$. pliensbachensis in the topmost Canadensis Am. Zone and Arnioceras assemblage "Zone" samples is compatible with the Semicostatum Am. Zone first occurrence in northwest Europe (Fig. 6). The subzonal marker species Parhabdolithus marthae is not present, possibly due to preservation.

The uppermost Sandilands Formation of Late Sinemurian age was sampled on Ghost Creek Road in central Graham Island and yielded relatively abundant, moderately well 


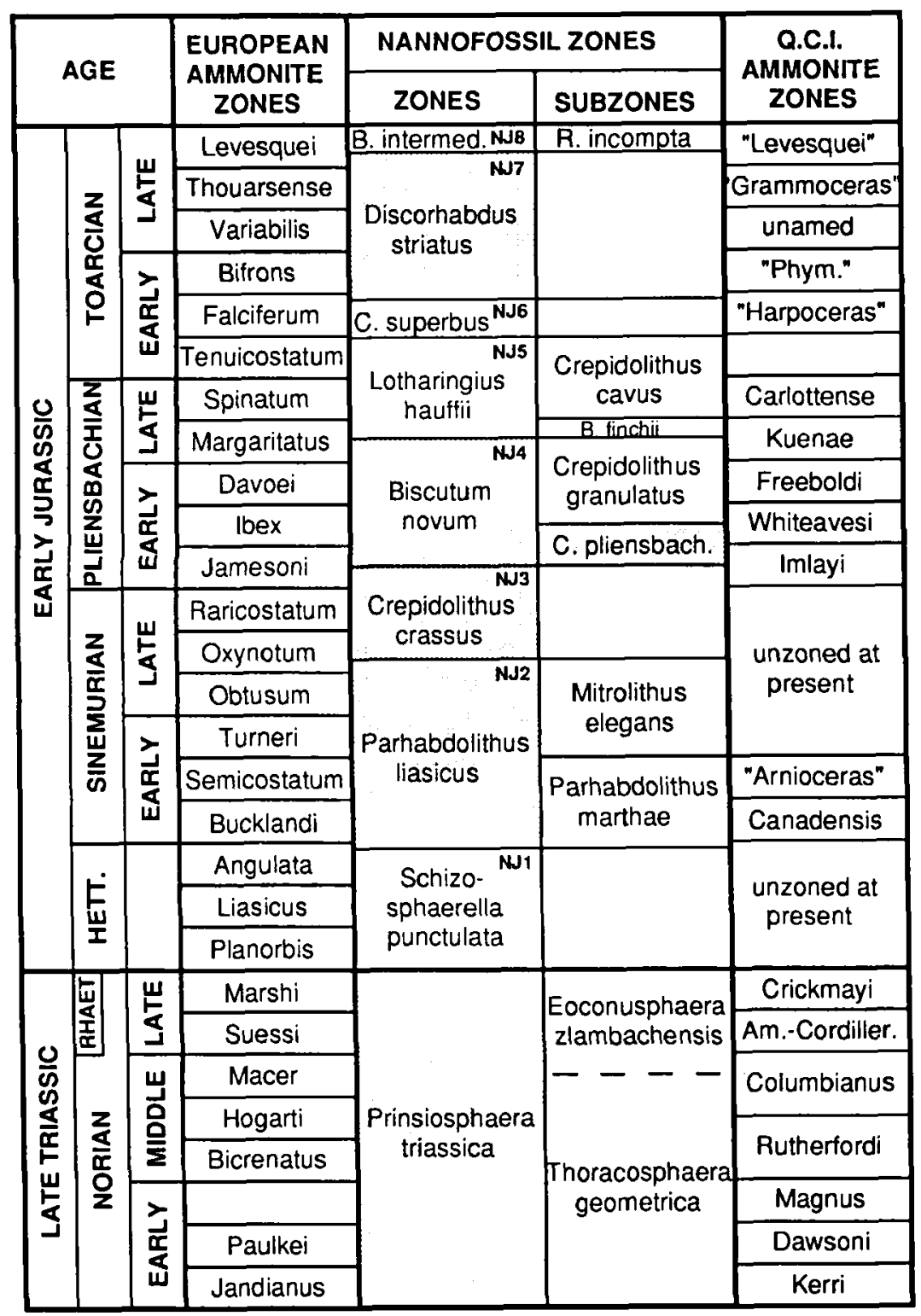

Fig. 6. Stratigraphy and biostratigraphy of the lower Mesozoic sequences of the Queen Charlotte Islands. Nannofossil zones are from Bown et al. (1988) (Lower Jurassic) and Bralower et al. (1991) (Upper Triassic). Queen Charlotte Island ammonite zones are based upon field observation summarised in Carter et al. (1989) (Upper Triassic) and Tipper et al. (1991) (Lower Jurassic). Shaded nannofossil zones have been identified in the Queen Charlotte Islands.

preserved nannofossil assemblages, consisting of Crepidolithus crassus, Crepidolithus pliensbachensis, Mitrolithus elegans, Parhabdolithus liasicus, P. robustus, and Tubirhabdus patulus. The assemblages are dated as NJ3 Crepidolithus crassus Zone (Oxynotum-Jamesoni Am. Zone).

Pliensbachian. Pliensbachian sediments of the Ghost Creek, Rennell Junction, and Fannin formations were sampled on Maude Island (stratigraphical section no. 8 of Cameron and Tipper, 1985) and at Whiteaves Bay on Moresby Island (stratigraphical section no. 7 of Cameron and Tipper, 1985). The Ghost Creek Formation (earliest Pliensbachian) consistently yielded relatively abundant nannofossil assemblages of variable preservation. The assemblages are generally dominated by Crepidolithus crassus and Mitrolithus elegans together with rarer Biscutum novum, Crucirhabdus primulus, Crepidolithus crassus, C. granulatus, C. pliensbachensis, Mitrolithus lenticularis, Orthogonoides hamiltoniae, Parhabdolithus liasicus, P. robustus, and Tubirhabdus patulus (Fig. 4). The assemblages are dated as NJ4 Biscutum novum Zone (JamesoniMargaritatus Am. Zone). Biscutum has a first occurrence within the Jamesoni Am. Zone in northwest Europe and its occurrence in these Ghost Creek Formation samples but not in the Ghost Creek Road samples indicates a first occurrence in the Imlayi Am. Zone in the Queen Charlotte Islands. The Imlayi Am. Zone is stratigraphically equivalent to the Jamesoni Ammonite Zone in northwest Europe (Fig. 6).

The late Early Pliensbachian and Late Pliensbachian Rennell Junction and Fanin formations were barren of nannofossils.

Toarcian. The Toarcian Whiteaves and Phantom Creek formations were sampled on the Yakoun River in central Graham Island (stratigraphical section no. 15 of Cameron and Tipper, 1985) and at Whiteaves Bay on Moresby Island (stratigraphical section no. 7 of Cameron and Tipper, 1985). The Whiteaves Formation was barren at Whiteaves Bay, but sporadically productive from the Yakoun River. The Whiteaves Formation shales were essentially barren of fine fraction calcite and assemblages were extremely rare and poorly preserved (etched). Assemblages were predominantly composed of Crepidolithus cavus, C. crassus, Lotharingius spp., Biscutum novum, and Discorhabdus striatus. Samples containing Lotharingius spp. are dated as NJ5 Lotharingius hauffii Zone (MargaritatusTenuicostatum Am. Zone) (Bown et al., 1988) or younger; and those containing D. striatus are dated as NJ7 Discorhabdus striatus Zone (Falciferum-Levesquei Am. Zone). The assemblages and biostratigraphy are comparable to that of northwest Europe, although the poor preservation makes any firm comparison difficult. The presence of questionable Lotharingius contractus and Watznaueria britannica in the upper samples dated as Grammoceras Am. "Zone" (G. Jacobs pers comm., 1990) (Thouarsense Am. Zone equivalent) suggests a first occurrence of these forms considerably earlier than those seen in northwest Europe (Aalenian and Lower Bajocian respectively).

Samples from the Phantom Creek Formation (latest Toarcian-Aalenian) were barren. 
Bajocian. The Graham Island Formation is of Early Bajocian age and consists of tuffaceous sandstone with rare shale interbeds. The formation was sampled on Branch Road 59, central Graham Island (stratigraphical section 13 of Cameron and Tipper, 1985). One sample yielded the dissolution resistant genus Watznaueria, which has a first occurrence in the Lower Bajocian in northwest Europe; the remaining samples were barren.

\section{Calcareous nannofossils from other early Mesozoic American sections}

Oregon. A small number of samples were taken from early Mesozoic sequences in the John Day inlier of central-east Oregon. The sequence was deposited within an island arc setting related to subduction along the continental margin (Dickinson and Thayer, 1978). A generalised stratigraphy is given in Figure 7. Lithologies include calcareous sandstone (Suplee Fm.); black shales (Nicely Fm.); volcaniclastic turbidites (Hyde Fm.); and conglomerates, siltstones, sandstones, and volcaniclastics (Snowshoe Fm.).

Most of the samples studied were barren of nannofossils: one sample from the Caps Creek Formation yielded rare Parhabdolithus liasicus; one sample from the Warm Springs Member yielded rare Lotharingius of $L$. crucicentralis.

\begin{tabular}{|c|c|c|}
\hline & Lonesome Fm. & BATHONIAN \\
\cline { 2 - 3 } & Snowshoe Fm & AAL-BAJ \\
\hline \multirow{2}{*}{0} & Hyde Fm. & TOARCIAN \\
\cline { 1 - 2 } & Nicely Fm. & $\begin{array}{c}\text { UPPER } \\
\text { PLIENSBACH. }\end{array}$ \\
\cline { 2 - 3 } & Suplee Fm & SINEMURIAN \\
\hline & Caps Creek Fm & SINEM \\
\hline
\end{tabular}

Fig. 7. Generalised stratigraphy of the John Day Inlier, Oregon (Dickinson and Thayer, 1978).

New York Canyon, Nevada. The Triassic/Jurassic boundary interval was sampled in the New York Canyon region of westcentral Nevada. This section has been proposed as the stratotype for the Triassic-Jurassic system boundary as it provides a record of nearly continuous sedimentation across the boundary interval and yields one of the most complete ammonite successions. The sequence is composed of alternating hard siltstone and limestone of Norian (including Rhaetian) to Pliensbachian age, and is divided into two formations and eight members (Taylor et al., 1983) (Fig. 8).

The sediments are thought to have been deposited in an autoch thonous cratonal basin, the Sonomia Basin, in basinal to shallow marine water depths. The New York Canyon strata were deposited in the shallowest marine area of the basin but contain good ammonite successions along with other macrofossils, e.g. bivalves, brachiopods and gastropods. Currently no microfossils have been recorded from the section and all samples prepared for nannofossil study were barren. Nannofossil absence is probably due to dissolution although their original absence cannot be discounted.

\begin{tabular}{|c|c|c|c|c|}
\hline \multirow{8}{*}{ 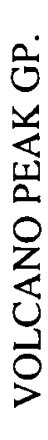 } & \multirow{5}{*}{ 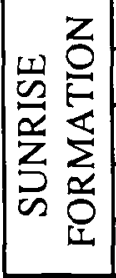 } & Mona Peak & \multirow{2}{*}{ Pliensbachian } & \multirow{5}{*}{ 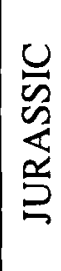 } \\
\hline & & Joker Peak & & \\
\hline & & New York Canyon & \multirow{2}{*}{ Sinemurian } & \\
\hline & & Five Card Draw & & \\
\hline & & Ferguson Hill & Hettangian & \\
\hline & \multirow{3}{*}{ 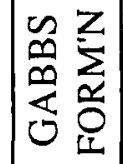 } & Muller Canyon & \multirow{3}{*}{ Norian } & \multirow{3}{*}{ 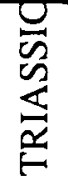 } \\
\hline & & Mount Hyatt & & \\
\hline & & Nun Mine & & \\
\hline
\end{tabular}

Fig. 8.Stratigraphy of the Triassic/Jurassicboundary sequence, New York Canyon, Nevada (Smith et al., 1983).

Nequen Basin, Argentina. Samples of Jurassic (Pliensbachain?Aalenian) age from the Nequen Basin were provided by Dr. Kielbowicz (YPF, Buenos Aires) and come from Picun Leufu Province in the Principal Cordillera of Argentina. The Nequen Basin was one of two narrow basins which formed at the end of the Triassic along the western margin of the South American sub-continent. Early Jurassic sedimentation was generally restricted to narrow and small basins which were marginal to the eastern Pacific Ocean.

Five samples yielded nannofossil assemblages (Fig. 9) which are most closely comparable with "Tethyan" assemblages from Portugal (Bown, 1987). Tethyan affinities are indicated by the presence of common Biscutum finchii and $B$. grande in the Pliensbachian-Toarcian, and Carinolithus magharensis and Triscutum sp. in the Late Toarcian-Aalenian. No other records of early Mesozoic nannofossils from South America have been published.

\section{Calcareous nannofossils from Timor}

Samples from the Upper Triassic and Lower Jurassic Aitutu and Wai-Luli formations from West Timor were collected by Simon Barkham (Royal Holloway and Bedford New College). These formations form part of an autoch thonous sedimentary sequence which was deposited in a relatively deep continental shelf sea at the northern edge of Australian Gondwanaland, the southern margin of eastern Tethys. Two sections were studied for nannofossils, from the River Anin and the River Meto (Kristan-Tollman et al., 1987).

Upper Triassic sediments from the River Anin section contain nannofossil assemblages consisting of Prinsiosphaera triassica, Eoconusphaera zlambachensis and Crucirhabdus minutus, which are closely comparable with Upper Norian (Rhaetian) assemblages from the Northern Calcareous Alps.

Lower Jurassic sediments from the River Meto section yielded nannofossil assemblages which indicate a SinemurianLower Toarcian age range including the NJ3, NJ4 and NJ5 nannofossil zones (Figure 10). A number of features of these assemblages are unique to Timor or indicate affinities with other Tethyan and low latitude areas. These are summarised as follows:

a. The abundance of Mitrolithus elegans in many of the samples is not typical of northwest European assemblages but is comparable with results from Eiberg, Austria (Bown and Lord, 1990) and the Queen Charlotte Islands assemblages 


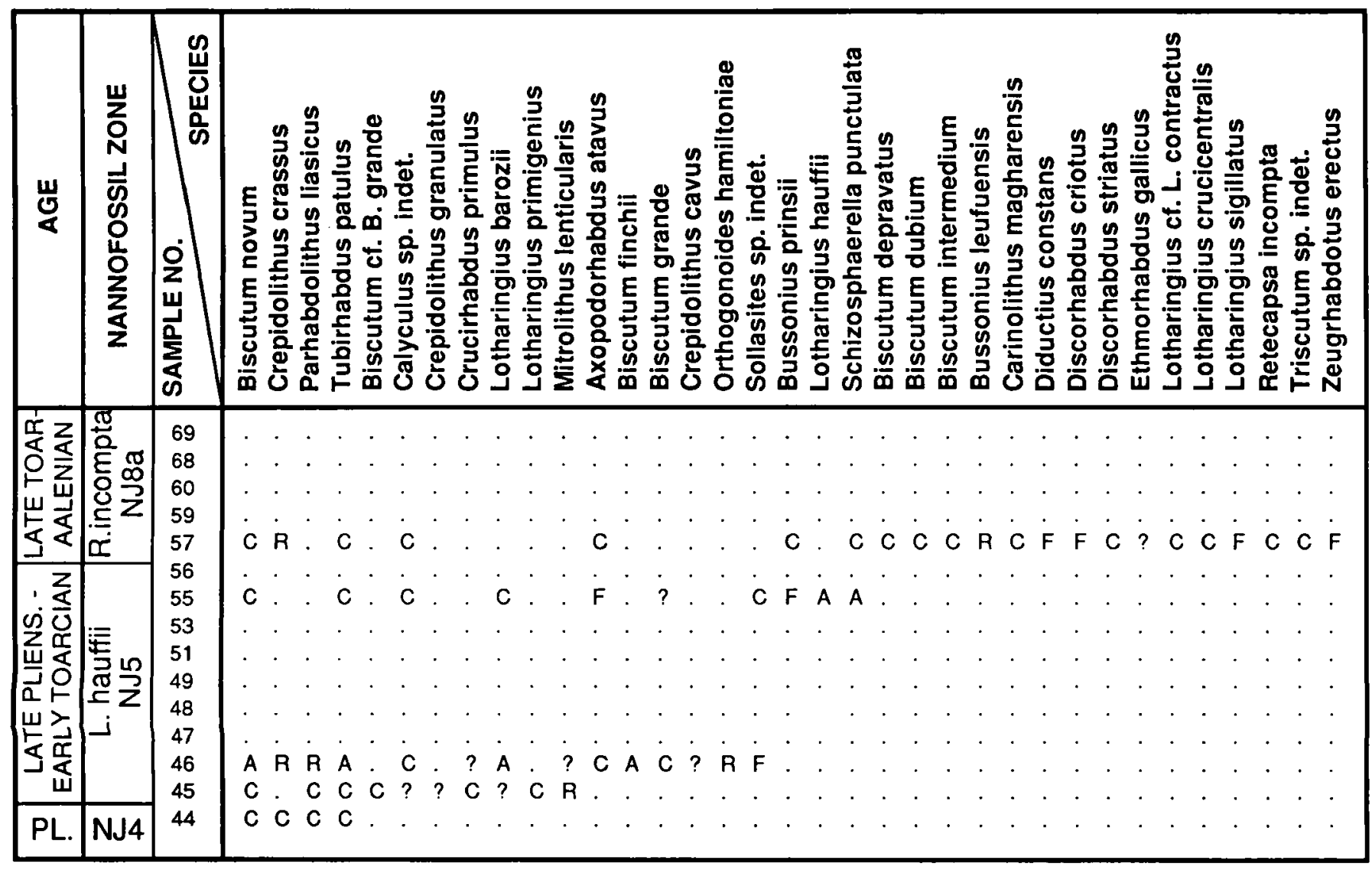

Fig. 9. Stratigraphical distribution of nannofossils from Picun Leufu, Nequen Basin, Argentina.

described here. In addition, specimens of $M$. elegans which have distinctive distal extensions of the spine (M. elegans var.1 in range chart) are observed in both the Timor and Eiberg assemblages (see Bown, 1987; p.27; Pl. 3, figs. 14-15).

b. The common occurrence of Crepidolithus timorensis, particularly in the Sinemurian, is observed in both the Timor and Eiberg sections.

c. Mitrolithus jansae, M. lenticularis, Parhabdolithus robustus, Biscutum finchii and B. grande are common in the Timor sections and these taxa are characteristic of Early Jurassic assemblages from western Tethys (Portugal, Italy, Tunisia). However, $M$. jansae is found more abundantly in assemblages of western Tethys. The taxa listed above are rare or absent in northwest Europe.

$\mathrm{d}$. The presence of Mazaganella pulla and M. protensa has only previously been recorded from Timor and DSDP Site 547 (offshore Morocco) (Bown, 1987, p. 113). Timorella cypella has been recorded from Timor only (Bown, 1987, p. 35).

\section{DISCUSSION}

The lack of early Mesozoic nannofossil data from the American continent is due to a number of factors, including unfavourable palaeogeography, post-depositional tectonism and metamorphism, and a general lack of carbonate-rich argillaceous marine sediments. The occurrence of calcareous nannofossils in the early Mesozoic sequences of the Queen Charlotte Islands represents the first record of this fossil group from Triassic and Lower Jurassic rocks of North America. The nannofossil assemblages from the Queen Charlotte Islands and from the Nequen Basin, provide the first evidence of nannofossil presence in the large Mesozoic Pacific Ocean to the west of Tethys. Their existence in marginal basins of the eastern Pacific suggests that nannoplankton had colonized the entire marine environment by the Early Jurassic. The lack of Triassic nannofossil records from high latitude regions may reflect more restricted distribution at this time but this is in need of further examination as research has only been carried out in northwest Europe, were favourable lithologies are rare. The overiding conclusion from the results presented here is that both Triassic and Early Jurassic nannofloras were for the most part cosmopolitan in distribution with only a small proportion of the total number of species displaying restricted distributions. Thenannofossil results from theQueen Charlotte Islands, Timor and Argentina confirm a sequence of successive evolutionary appearances of taxa which can be recognised over a wide geographical area but also show features of provincialism which allow biogeographical subdivision. The only disappointing aspect of the results is the poor preservation of the nannofossils from the Queen Charlotte Islands which is almost certainly reflected in lowered diversities and possible distortion of stratigraphical ranges. Despite this, a number of conclusions may be drawn concerning palaeobiogeography and biostratigraphy. 


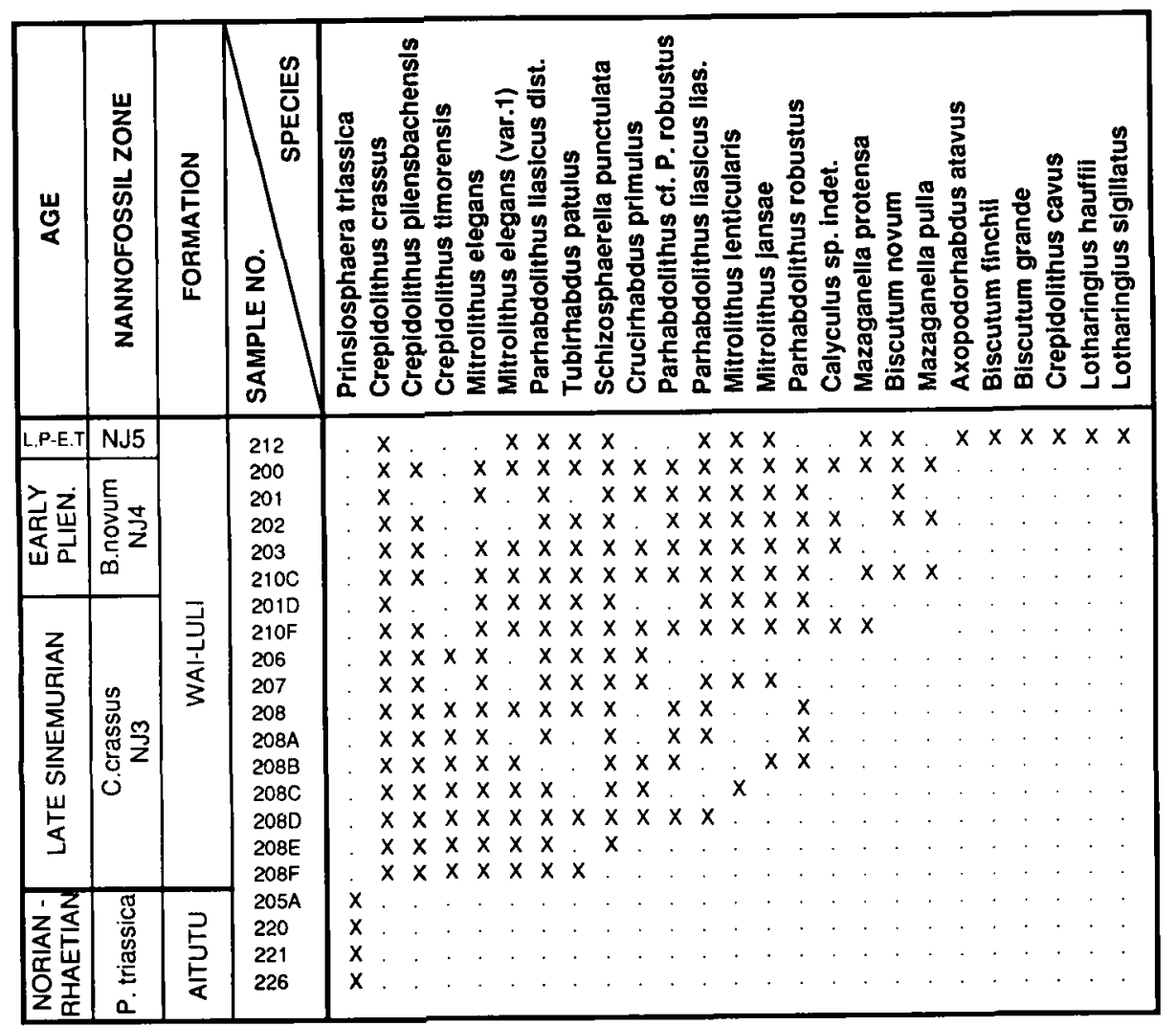

Fig. 10. Stratigraphical distribution of nannofossils from the River Meto section, Timor.

these forms at or very near to the Triassic/Jurassic boundary level.

\section{Early Jurassic nannofossil biogeography}

As for the Late Triassic, our understanding of Early Jurassic nannofossil biogeography is limited by the geographical restriction of the data. The only productive sections known from the immense Eastern Tethys-Pacific oceanic area are from Timor, Argentina (Nequen Basin) and the Queen Charlotte Islands.

In the European/Western Tethys/proto-Atlantic region the nannofloras broadly delineate a northern (high latitude), Boreal province and a southern (low latitude), Tethyan province. The provincialism is shown by limited endemism (mainly endemic Tethyan taxa) and differences in species dominance. The most striking Tethyan marker is Mitrolithus jansae which often dominates assemblages throughout its Sinemurian to Early Toarcian range (Bown, 1987). Other taxa which are only found commonly in the Tethyan province include Biscutum grande, Mitrolithus lenticularis and Mazaganella pulla.

\section{Triassic calcareous nannofossil biogeography}

The Triassic nannofossil assemblages from theQueen Charlotte Islands compare well with those described from the Northern Calcareous Alps (Moshkovitz, 1982; Jafar, 1983; Bown and Lord, 1990), Timor (this paper), and the northwest Australian shelf (Bralower et al., 1991). In all cases the assemblages are abundant and of low species diversity, dominated by the spherical nannolith, Prinsiosphaera triassica, together with rarer Thoracosphaera spp., and the small coccolith Crucirhabdus minutus. The only major discrepancy between the assemblages observed is the absence of Eoconusphaera zlambachensis in the Queen Charlotte Islands. In the Northern Calcareous Alps, E. zlambachensis is commonly a significant assemblage contributor. It is found more rarely in material from Timor and northwest Australia (Fig. 11). It has a stratigraphical range through the Middle and Upper Norian, which is well represented in the Queen Charlotte Islands. From an albeit rather restricted data set its distribution appears to display an abundance gradient from western to eastern Tethys (becoming rarer to the east) and a complete absence in the eastern Pacific. This distribution pattern is also shown by Mitrolithus jansae in the Early Jurassic.

Although the widespread distribution of Late Triassic nannofloras is steadily being demonstrated, their biostratigraphical utility is limited by low species diversity. However, abundant Prinsiosphaera is confirmed as a good marker of the Norian (and "Rhaetian") as is the extinction of
Tethyan nannofossil assemblages have been reported from Italy (e.g. Young et al., 1986; Reale, 1989; Cobianchi, 1990), Portugal (Bown, 1987), Tunisia (Bown, 1987), and offshore Morrocco (DSDP Site 547) (Bown, 1987). The assemblages from Timor and Argentina also display features indicating Tethyan affinities, as described above, however, $M$. jansae is rare in Timor and absent in Argentina. Boreal assemblages are known from the northern hemisphere only, e.g. Britain, France, Germany and Holland.

The Early Jurassic nannofossil assemblages from the Queen Charlotte Islands are broadly comparable with those of northern Europe in terms of both assemblage components and stratigraphical ranges. The biozonation scheme of Bown et al. (1988), which was developed in northwest Europe, was applied successfully. The Tethyan marker, $M$. jansae, is absent from the material and only the rare occurrence of $M$. lenticularis, points to speculative Tethyan affinities. The most interesting feature of the assemblages is the absence of $S$. punctulata, an incertae sedis taxon, which is a common-abundant component of nannofossil assemblages in both Boreal and Tethyan provinces in the European region. S. punctulata is present in Pliensbachian material from Timor but absent in Argentina (although it is abundant in Toarcian material from Argentina) (Fig. 11). Its absence in the Queen Charlotte Islands is surprising considering its abundance in both the European epicontinental sea and the Tethys Ocean. Similarly, the absence of $M$. jansae is unexpected, particularly as it appears to characterise Tethyan 


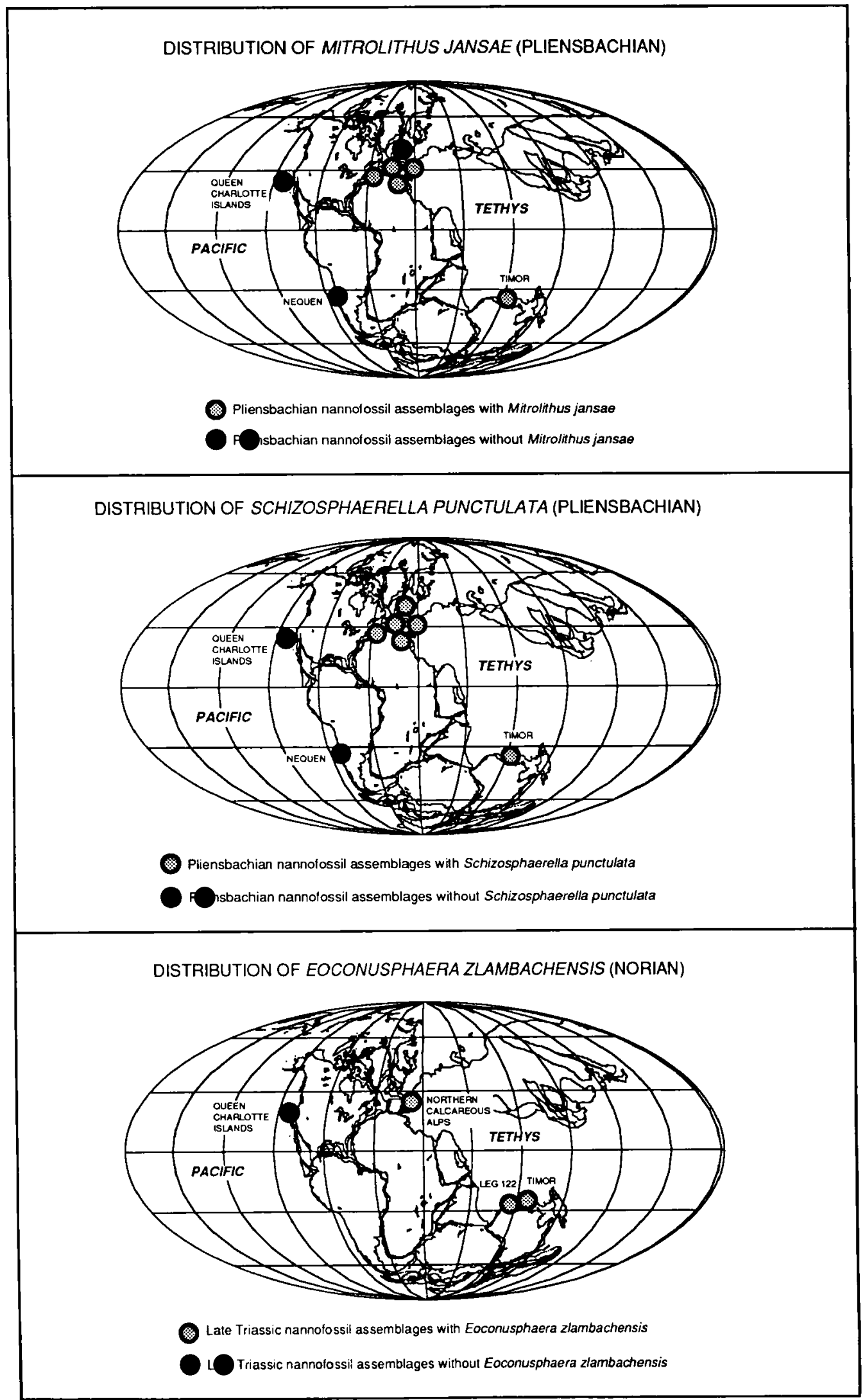

Fig. 11. Palaeobiogeography of Eoconusphaera zlambachensis (Upper Triassic), Schizosphaerella punctulata (Pliensbachian) and Mitrolithus jansae (Pliensbachian). Reconstruction fro'm Terra Mobilis. 
assemblages, being present both in western and eastern Tethys (although it is rarer in eastern Tethys) (Fig. 11).

Although data are still too scarce to draw firm conclusions concerning global distribution patterns for this time interval, it appears probable that certain species were present in the Tethys/proto-Atlantic and in certain cases further north, but did not colonise the Pacific Ocean (or at least the eastern Pacific margins) at all, or not until a later date. This kind of distribution pattern appears to be displayed by E. zlambachensis in the Late Triassic and by $S$. punctulata and $M$. jansae in the Pliensbachian. Comparable distribution patterns are also observed for certain younger Mesozoic nannofossil taxa, e.g. Nannoconus and Conusphaera in the Late Jurassic, both of which had evolutionary appearances in the western Tethys/ proto-Atlantic and remained abundant but restricted in distribution.

A number of explanations for this kind of distribution may be offered:

1. Temperature - latitudinally zoned provinces controlled primarily by differing temperatures are thought to account for the broad patterns of living and fossil nannoplankton distribution. The Queen Charlotte Islands are thought to have occupied a low latitude position at this time but nannofossil assemblages do not include Tethyan taxa such as $M$. jansae or supposedly cosmopolitan taxa, such as $S$. punctulata. Straightforward temperature control can not, therefore, account for these distributions.

2. Preservation - the missing species are all robust, particularly S. punctulata, thus dissolution can not account for their absence in assemblages which retain more delicate forms.

3. Water depth - all the missing taxa have been found across a wide range of non-oceanic water depths, however, no early Mesozoic oceanic assemblages have as yet been reported. The presence of many of the early Mesozoic taxa around both Tethyan and Pacific margins suggests that the open ocean was not a significant physical or ecological barrier to distribution. However, those taxa which are essentially restricted to Europe, the proto-Atlantic and Tethys may have been ecologically limited to the ocean margins (the limiting factor being possibly related to nutrient availability) and were thus unable to cross the Pacific during Triassic and earliest Jurassic time. The presence of S. punctulata in the Argentinian section in the Toarcian may indicate that a route to the eastern Pacific had opened up by this time, most likely via the Central American Seaway/Hispanic Corridor.

\section{CONCLUSIONS}

1. The majority of Early Jurassic nannoplankton were cosmopolitan in distribution. However, a small number of endemic species and differences in species abundances allow the recognition of Boreal and Tethyan provinces.

2. Upper Triassic nannoplankton have now been reported from low latitude sites in both the Tethys and Pacific oceans, suggesting at least global equatorial distribution at this time.

3. Certain taxa are limited in distribution to Europe, the proto-Atlantic, and Tethys, and may have been prevented from colonising the Eastern Pacific due to ecological factors related to water depth. This barrier would have been removed once the Central American Seaway opened.
4. The Bownet al. (1988) nannofossil zonation scheme for the Lower Jurassic was successfully applied to the Queen Charlotte Islands material.

\section{ACKNOWLEDGEMENTS}

The research was initially funded by a Natural Environment Research Council ODP Special Topic Research Fellowship. Assistance and guidance in the field was provided by the Geological Survey of Canada, thanks particularly to Mike Orchard, Beth Carter, Howard Tipper, Jim Haggart, Gizelle Jakobs, and Jozsef Palfy; and by Dave Taylor (Portland State University). Argentinian samples were kindly provided by Ana Kielbowicz (YPF, Buenos Aires) and Timor samples by Simon Barkham.

\section{Manuscript received February 1992 \\ Manuscript accepted July 1992}

\section{REFERENCES}

Bown, P.R., 1987. Taxonomy, biostratigraphy and evolution of late Triassic-early Jurassic calcareous nannofossils. Special Papers in Palaeontology, 38, 1-118, Oxford.

Bown, P.R., Cooper, M.K.E., and Lord, A.R. 1988. A calcareous nannofossil biozonation scheme for the Early to Mid Mesozoic. Newsletters on Stratigraphy, 20 (2), 91-114, Berlin-Stuttgart.

Bown, P.R. and Lord, A.R. 1990. The occurrence of calcareous nannofossils in the Triassic/Jurassic boundary interval. Les Cahiers de l'Universite Catholique de Lyon, Serie Sciences, 3, 127-136, Lyon.

Bralower, T.J., Bown, P.R., and Siesser, W.G. 1991. Significance of Upper Triassic nannofossils from the Southern Hemisphere (ODP Leg 122, Wombat Plateau, N.W. Australia). Marine Micropaleontology, 119-154, Amsterdam.

Cameron, B.E.B. and Tipper, H.W. 1985. Jurassic stratigraphy of the Queen Charlotte Islands, British Columbia. Geological Suriey of Canada, Bulletin 365, 49pp, Ottawa.

Carter,E.S., Orchard, M.J., and Tozer, E.T. 1989. Integrated ammonoidconodont-radiolarian biostratigraphy, Late Triassic Kunga Group, Queen Charlotte Islands, British Columbia. Geological Survey of Canada, Current Research, Part H - Paper 89-1H, 23-30, Ottawa.

Cobianchi, M. 1990. Biostratigraphia a nannofossili calcarei del passaggio Domeriano-Toarciano in Val Navezze (Brescia). Atti Ticinensi di Scienze della Terra, 33, 127-142, Pavia.

Dickinson, W.R. and Thayer, T.P. 1978. Paleogeographic and paleotectonic implications of Mesozoic stratigraphy and structure in the John Day Inlier of Central Oregon. In Howell, D.G. and McDougal, K.A. (Eds), Mesozoic paleogeography of the u'estern United States: Pacific Coast Paleogeography Symposium 2, Sacremento, Calif., SEPM, Pacific Section, 147-162.

Hesthammer, J., Indrelid, J., Lewis, P.D., and Orchard, M.J. 1991. Permian strata on the Queen Charlotte Islands, British Columbia. Geologicnl Survey of Conada, Current Research, Part A - Paper 91-1A. 321-329, Ottawa.

Jafar, A.S. 1983. Significance of Late Triassic calcareous Nannoplankton from Austria and Southern Germany. Neues Jalurbuch fur Geologie und Palaontologie Ablandlungen, 166(2), 218-259.

Kristan-Tollman, E., Barkham, S. and Gruber, B. 1987 Potshenschichten, Zlambachmergel (Hallstatter Obertrias) und Liasfleckenmergel in Zentraltimor, nebst ihren Faunenelementen. Mitt. osterr. giol. Ges., 80, 229-285.

Moshkovitz, S. 1982. On the findings of a new calcareous nannofossil (Conusphaera zlambachensis) and other calcareous organisms in the Upper Triassic sediments of Austria. Eclogae Geologicae Helvetiae, 75, 611-619. 
Reale, V. 1989. Jurassic calcareous nannofossils and benthic foraminifera in the Valdorbia section. In Cresta, S., Monechi, S. and Parisi, G. (Eds), Mesozoic-Cenozoic stratigraphy in the UmbriaMarche area. Memorie descrittive della Carta Geologica D'Italia, XXXIX, 80-88.

Smith, P.L. and Tipper, H.W. 1989. Biochronology, stratigraphy and tectonic setting of the Pliensbachian of Canada and the United States. In Rocha, R.B. and Soares, A.F. (Eds.) 2nd International Symposium on Jurassic Stratigraphy, Lisboa 1987, , 1, 119-138, Lisbon.

Sutherland Brown, A., Yorath, C.J. and Tipper, H.W. 1983. Geology and tectonic history of the Queen Charlotte Islands. Geological Association of Canada, Field Trip Guide Book, Trip, 8, 21pp, Victoria B.C.

Taylor,D.G.,Smith, P.L., Laws, R.A. and Geux, J. 1983, The stratigraphy and biofacies trends of the Lower Mesozoic Gabbs and Sunrise formations, west-central Nevada. Canadian Journal of. Earth Science, 20, 1598-1608.

Tipper, H.W., Smith, P.L., Cameron, B.E.B., Carter, E.S., Jakobs, G.K. and Johns, M.J. 1991. Biostratigraphy of the Lower Jurassic formations of the Queen Charlotte Islands, British Columbia. In Woodsworth, G.J. Evolution and hydrocarbon potential of the Queen Charlotte Basin, British Columbia, Geological Survey of Canada, Paper 90-10, 203-235.

Young,J.R., Teale,C.T. and Bown, P.R. 1986. Revision of the stratigraphy of the Longobucco Group (Liassic, southern Italy); based on new data from nannofossils and ammonites. Eclogae Geologicae Helvetiae, 79, 117-135.
List of nannofossil taxa cited in the text

Biscutum finchii Crux 1984

Biscutum grande Bown 1987

Biscutum novum (Goy 1979) Bown 1987

Carinolithus magharensis (Moshkovitz \& Ehrlich 1976) Bown 1987

Conusphaera Trejo 1969

Crucirhabdus minutus Jafar 1983

Crucirhabdus primulus Rood et al. 1973

Crepidolithus cavus Rood et al. 1973

Crepidolithus crassus (Deflandre 1954) Noel 1965

Crepidolithus granulatus Bown 1987

Crepidolithus pliensbachensis Crux 1985

Crepidolithus timorensis Kristan-Tollman 1988

Discorhabdus striatus Moshkovitz \& Ehrlich 1976

Eoconusphaera zlambachensis (Moshkovitz 1982) Bown \& Cooper 1989

Lotharingius contractus Bown \& Cooper 1989

Lotharingius crucicentralis (Medd 1971) Grun \& Zweili 1980

Mazaganella protensa Bown 1987

Mazaganella pulla Bown 1987

Mitrolithus elegans Deflandre 1954

Mitrolithus jansae (Wiegand 1984) Bown \& Young in Young et al. 1986 Mitrolithus lenticularis Bown 1987

Nannoconus Kamptner 1931

Orthogonoides hamiltoniae Wiegand 1984

Parhabdolithus liasicus Deflandre 1952

Parhabdolithus marthae Deflandre 1954

Parhabdolithus robustus Noel 1965

Prinsiosphaera triassica Jafar 1983

Schizosphaerella punctulata Deflandre and Dangeard 1938

Thoracosphaern geometrica (Jafar 1983) Bown 1987

(=Orthopithonella geometrica (Jafar 1983) Janofske 1987)

Timorella cypella Bown 1987

Triscutum Dockerill 1987

Tubirhabdus patulus Rood et al. 1973

Watznaueria britannica (Stradner 1963) Reinhardt 1964 